\title{
Comparison of Zhongnan Culture and Nomadic Culture
}

\author{
Jie Hang \\ College of Art \\ Xi'an Fanyi University \\ Xi'an, China
}

\begin{abstract}
Zhongnan Mountain, is a boundary of the south and north part of China. Zhongnan Culture, a regional culture, is formed based on this unique geological location. As a geological boundary in Culturology, Zhongnan Mountain only reaches Shangluo, Ankang Mountainous area in south, and reaches South of Guanzhong in north. Its location shows Zhongnan Culture is obviously different from strictly mentioned shifting-cultivation Culture in Han-Jiang River Basion, especially with Normadic Culture in Shanbei Plateau. This paper analyzes the above mentioned characteristics by comparision of Zhongnan Culture and Shanbei Plateau's Normadic Culture.
\end{abstract}

Keywords-Zhongnan culture; nomadic culture; cultural mentality

\section{INTRODUCTION}

Zhongnan Mountain, as part of Qinling Mountains, divides the south and north part of China. It is called by Mr Wang Ruobing "Father Mountain of Chinese Nation". Zhongnan Culture, a regional Culture, is formed based on this unique geological location. Culture varies in different forms; by Zhongnan Mountain's unique geological location, Zhongnan Culture merges its south part's shifting-cultivation production style with its north part's farming production to some degree, but it is almost isolated with Shanbei Plateau's nomadic productivity. Zhongnan Culture differs from Nomadic culture completely in production style, culture mood and nation's characters.

\section{FIXITY AND MOBILITY: COMPARISON OF PRODUCTION STYLE}

Jianghan Plain, in the south of Zhongnan Mountain, is engaged in shift-cultivation or fish-hunting production. The Guanzhong Plain in the north of Zhongnan Mountain is typical farming production. Shifting cultivation refers to extensive cultivation while harvesting based on yearly rainfall amount, and farming means intensive cultivation in a crisscrossed block of field; but both of them are production; that's why Zhongnan culture can fuse them together. Shifting-cultivation also exists in Shanbei Plateau (North of Shaanxi), however the crop yield cannot support people's daily life, and therefore most of people there choose nomadic production. Shanbei is also political and military conflict area between nomadic nation and agricultural nation. Even the compatibility of Zhongnan Culture cannot remove above mentioned difference, thus formed different characteristics of Zhongnan Culture and Nomadic Culture.

\section{A. Fixity and Migration in Land}

Caocuo said in his Lun Gui Su Shu that farming production "is born in land", he stressed "undeveloped state of land", and that "soil for grown crops haven't been fully cultivated, and mountain and rivers haven't been completely utilized", all of which are emphasizing close relationship between farming production and land. Oranges grown in south of Huai River are sweet oranges, while grown in north of Huai River become trifoliate orange. A plant is only suitable to be grown in a designated land. If grown in another kind of land, it will have different tastes, though still with similar leaves; thus fixity is formed in farming production. Zhongnan Mountain, including both south and north parts, is engaged in this kind of "landborn" farming production. Generations of people excavate undeveloped lands, enrich poor soils for crops, and cultivate them into "most fertile" lands. Lands are roots of farmers; the highest goal for Guanzhong People is that farmers have lands. Land becomes an important symbol of one's wealth.

It is drought and cold in Shanbei (North of Shaanxi), and the land is barren, on which wheat and rice can barely grow up People can only grow some upland crops in special season, such a millet, sorghum, potatoes and sweet potatoes, etc. So Ou Yang xiu said in his "Mingfeiqu": "Hu people take hommelled horses as home, hunting as custom; They migrate from place to place to search for rich land and sweet water and to hunt animals" No farming land, no fixed residence, they live on nomadism. They do not dig wells for drink or farm for food; instead, they migrate or move to search for these things. This kind of production is out of imagination in the eyes of Zhongnanshan People, whose production is traditionally "fullutilization of lands".

\section{B. Seasonal Circularity and Mobility}

Farming production follows season; spring ploughing, summer weeding, autumn harvesting and winter storing. Seasonal circulation is unchangeable through ages. Compared with rice production in south area, Guanzhong plants wheat in late autumn and fertile and water them during winter. The saying "fertilizer is gold in lunar December and is silver in January", also shows importance of seasonal fertilization. "Farmers don't have any free time, and they are especially 
busier in May (FR Guan Yimai by Baijuyi). Farmers not only weed in summer, they also harvest wheat and sow maize and millet, which are commonly known as three busy things. Winter wheat cannot grow up in Shanbei Plateau, so people there plant plants such as millet, sorghum, potatoes and sweet potatoes, etc and harvest in late autumn. There are almost no farm activities in spring and winter, so people there have stronger mobility in production.

\section{Working Pragmatism and Idling}

Farming production "focuses on working". The whole process is very pragmatic, concentrate and fixed; each part of plantation must rely on climate and season; while for nomadic production in Shanbei Plateau, people herd flocks of sheep and cattle, rather than feeding one by one; this obviously shows that nomads are not as pragmatic as farmers, and they are idling in production

From above, we can see that Zhongnan Culture with farming production is fixable, circular in season and is pragmatic; while Shanbei nomad is migrated, mobiling and idling.

\section{FENCE COMPLEX AND WATCHING MOOD: COMPARISON OF CULTURAL PSYCHOLOGY}

The fixed farming production in the north of Zhongnan Mountain caused people's fence complex; while Shanbei people formed watching mood due to their nomadic production style. Both of them are shown in many aspects in people's physical and mental lives.

A military writer from Xinjiang Province, Mr Zhoutao, studied the Great Wall, and found that the Great Wall actually "is a division wall of farming nation and nomad people". The great wall builders in the north foot of Zhongnan Mountain were very tough and hardworking; they built most part of the great wall at over $2000 \mathrm{~m}$ sea levels. They are also cunning as they "circled drinking water inside the wall, and leave the undrinkable and bitter water outside the wall", thus the living environment inside the wall are better than that outside the wall. So China's two-thousand years' history, actually, is a history of two nations fighting for good living environment. To defend or to attack the great wall becomes a joint point for their fighting. Psychological structure of two nations' material and mental culture are derived from their attack and the defense

\section{A. Material Is Survival; the Different Living Environment Inside and Outside the Great Wall Caused Different Psychologies of Attack or Defense, Protection or Gazing, Guarding and Watching}

The Great Wall is a big fence, that closely embosoming the farming people, and completely isolating the nomadic people. A variety of walls are built inside the Great Wall, such as fences between families, villages and cities near Zhongnan Mountain. Chang'an city wall is the greatest one, inside of which lived the royal family. Every wall protects this nation. Men farming and women weaving are the most ideal production and life-style. In this severely guarded land, men work hardly in fields with waist bent year by year. "Women, with baskets, walked through the lane to pick mulberry leaves" (FR "Book of Songs"), and they do spinning and weaving inside their home. People have always wanted to protect the wall since the Qin Dynasty; Emperor Hanwu once opened the wall and send General Weiqing to attack nomadic nation actively, but the ultimate goal was for better protection of the wall. Even in late feudal period, Emperor Zhu Yuanzhang also adopted Zhu Sheng's "high wall" advice, and not only restored the Great Wall, but also built many large and small walls all over the country, which strengthened nation's wall complex again. Lu Xun, a famous writer in modern times, mentioned "always felt surrounded by walls" when revealing inferiority of nation people. "The composition of the wall is old bricks and new added bricks; both, combined together, create the barrier among people". Mr Luxun sighed:" when people will not add new bricks to the wall?" (FR "Huagaiji, Great Wall").

However, the nomadic people outside the great wall did not want to build up all kinds of walls. They were not only disgusted but also scornful to the big wall that had locked them outside. In the thirtieths year of Emperor Kangxi (1691), Cai Yuan, the commander-in-Chief of Gubeikou Pass report to the emperor that "many parts of the great wall wre collapsed" and suggest "repair the collapsed parts". Emperor Kangxi rejected the suggestion directly, and said: "reparation needs conscription of labors; how could it do no harm to people? Besides, The Great Wall is thousands of miles long, how many soldiers I need to support to guard the wall?" It makes Qing dynasty as the first dynasty that barely repair the great wall, which just reflects nomadic people's antipathy to the great wall. Shanbei people learned "cave dwelling" from ancestors of Guanzhong farming people; "cave dwelling" life-style refers to hoop caves, instead of building houses, which was first adopted but abandoned later by Guanzhong people. Walls between caves are only used to prevent wild animals. There are no walls and it's also impossible to have walls in mountain plateau for herding sheep and cattle. When they herd cattle and sheep, they "always like to stand on the top of the slope where is full of cattle and sheep and look far into distance", look at the world inside the wall. "The sweet scented osmanthus in autumn and miles of lotus flowers in summer inside the wall" even aroused King of Jin Wanyan Liang's ambition of entering the wall and conquer the south, which reflects nomadic people's longing to the world inside the wall. Many nations, such as Huns, Khitan, Nvzhen, Daxia and Tangut who lived outside the wall wanted to break the wall; Mongolia broke once and established Yuan Dynasty, and so did Qing people. The constant attack to the wall made them look down upon the wall radically. Emperor Kangxi once said in rejecting the suggestion of repairing wall that "at the end of Ming Dynasty, the First Emperor of Qing led the troops broken the wall directly with irresistible force; Ming's troops were defeated and collapsed although with wall", which shows that the wall is actually useless. That's why Emperor Kangxi stressed that "the root for running a country is to improve people's merits and assure people a peaceful life. People's fondness and supports strengthens governing of the country; thus the frontier defense will be stronger gradually. That is socalled: united wills can be a fortress." Mr Luxun also said about the great wall: "many workers died in vain to build the 
wall, however the wall still couldn't withstand Hun's attack." (FR "Huagaiji, Great Wall").

\section{B. The Attack and Defense to the Wall Resulted in Different Psychologies of Two Nations Inside and Outside of the Wall, Which Is Obedience and Rebellion}

Political and power center was located in north of Zhongnan Mountain for long time. Politics admire power; power relies on titular honors, which can bring benefits. Guanzhong people are easier to accept governor's value, and are easier to become obedient people. "Acquire cultural and military talents, and serve the royal family". Many people try their best to enter the official circle, and they adapt to it easily. Of course they hope the dynasty inside the wall can last forever, so they can keep their official rank and honors. As long as they keep their official rank and honor, they can have salaries; and as long as they have land, they can have income.

Shanbei People did not want emperor's dynasty lasted forever. Where there were rich water and grass, where they herded cattle and sheep. They didn't want to stay on that barren land forever. They always longed for going down south through the wall to run horses and herd cattle and sheep on thousands acres of fertile fields. Farming people repaired the incomplete Great Wall with their hands again and again, but nomadic people's cavalry made the wall lost its significance time and time. Many ethnic groups entrenched in Shanbei, such as Quanrong, Guifang, Xianyun, Huns, Dangxiang, Qiang, Xianbei, Jie, Di, daxia, Xixia, etc attempted to attack the south. Although Xixia people were kept out by Mr Fan Zhongyan, and lamented "Fan's military talents equals to millions of soldiers", Daxia's leader, Haolian Bobo, conquered Chang'an for many times. It seems the First Emperor of Qin Dynasty, who was the first emperor to build the great wall, didn't have large desires, in spite of his bold spirits and achievements in ruling the six kingdoms. Compared with Mongolian people's vast land, or even with Qing Dynasty's land (the last dynasty in China), Qin Dynasty's territory founded by Emperor Qinshihuang was quite small. This indicates that the nomads' aspiration and the acceptance to different nationalities are obviously grander.

Obviously, Zhongnan culture has closer connection with feudal politics, and it does not absorb nomadic culture's grand breadth of mind. It has more wall complex and farming people's values, which are stable, satisfying and closed; and it has less nomadic people's vision and is lack of expand enterprising and pioneering spirit in a wider range.

\section{OBEDIENCE AND REBELLION: COMPARISON OF PEOPLE'S CHARACTERISTICS}

Wall complex of farming people near Zhongnan Mountain makes them more acceptable to ruler's values and be more obedient to ruling. While Shanbei People's far-distance looking attitude makes them dissatisfied with current situation, and are easily to get rebellious.

\section{A. Both the Obedience of the Farming Nation and the} Rebellion of the Nomadic People Are Attached to Group, While Obedience People Rely on Power and Rebellion People Admire Strength

People under Zhongnan Mountain are obedient to power, so they blindly follow the Confucian thoughts and ethics, which protect power. The core value of Rites of Zhou is to maintain political "hierarchy" system during implementation of blood-tie relationship, to "restrict upper and lower level with morality, thus the emperor, ministers, scholars, and common people are all under same restraint by morality", which ensures "only one leader in the country and one master in a family". The emperor buried in Guanzhong Wuling Plain is the advocator for loyalty and filial piety. The moral models buried with the emperor, including local ministers, martyrs, filial people, and virtuous women, etc are all reflection of loyal and filial piety. Many villages set chastity memorial arches in Guanzhong Plain, which praise people who change loyalty and filial piety to extreme and false loyalty and filial.

The nomads in Shanbei plateau are seldom influenced by this ethical morality, and are more likely to become natural people without ethical taming and contamination. In Romance of the Three Kingdoms, Lv Bu, born in Inner Mongolia prairie, is such a person. No one can defeats him in martial arts, even "three heroes" cannot win him; however in orthodox Confucian ethics, he has been mocked and demeaned; even Zhangfei, born in a butcher family, mocked at him as "slave of three families". In fact, this "west cowboy" hero and the livingstyle of "living where there is water and water" make him a natural and free man who is not tamed and contaminated by Confucian moral ethics. He doesn't have deep-rooted loyalty to anyone, and he always adapts himself to the changing situation. He lives only for himself, and he is uncommitted in ethics aspects. Compared with $\mathrm{Lv} \mathrm{Bu}$, Guan $\mathrm{Yu}$ and $\mathrm{Lv}$ Mengtoo are too rigid and serious; Zhang Fei, $\mathrm{Xu} Z \mathrm{Zhu}$, and Dian Wei etc., are too vulgar and arrogant; Zhao Yun and Ganning are too loyal and too reserved; only Machao, born in Qiang's high-hierarchy family and more restrained compared with Lvbu, has same kind of freedom spirits because they are initially motivated by same nomadic culture.

\section{B. Two Nations' Productions Have Different Attachment with Power, Which Also Influenced Their Obedience and Resistance Characteristics}

As Marx said, due to the East's geographical and climatic condition, Family household and self-sufficient style of production is adopted in farming production under Zhongnan Mountain. To guarantee normal farming production, a strong and powerful government is needed to organize millions of people to build giant water conservancy projects in peace time and to defend invasion of North people during wartime; thus high-centralized politics and power is formed in feudal society, and consciousness of imperial power is deeply rooted in producers' minds.

The nomads rarely built huge water conservancy projects in Shanbei. They were looking for a natural "spring \&water"; once they lost them, they would be grieved and lamented:" Losing Yanzhi Mountain, women are less beautiful; losing 
Qilian Mountain, even their livestock don't propagate" (FR Hun's Song). During fight with farming people, "they are more group-like and more easily to be driven for the same goal" but their emotion is transient and they lack of enduring strength because most of them are instigated and coerced by the group; so they don't have much consciousness of imperial power. There are many moving stories about loyalty, filial piety, chastity and righteousness in Qinqiang Opera (Shaanxi Opera), that's why the singing is very impassioned and inspiring.

\section{Those Who Followed Productivity Developments Are Called Obedience People; and Those Struggled Against It Are Rebellion People}

There are rebellions, too, in farming production; Chen Sheng and $\mathrm{Wu}$ Guang were tenant peasants and they had no land; Huang Chao failed his imperial-exam and Song Jiang lost his ambition in his official career; neither of them could become a ruler, therefore they longed for amnesty from government after rebellion. There were also strong man in south of Shaanxi, but they were at most thieves robbing local people. They are described as "robbers in Guanzhong Mountain" in novel "Bai Lu Yuan"; in the book, Bai Jiaxuan reminded his son to be aware of the "Guanzhong Robbers". Tough folk customs in Guanzhong only makes "swordsman" famous. Many young people from rich families applied for Huangpu Military school, and many of them became leader of Kuomintang Party. Young people from poor families seldom come to Yan'an, not even mention Xian's intellectuals. Until today, Xi'an people still look down upon Shanbei people who work in Xi'an or settle down in Xi'an.

Mr. Zhou Tao discovered from the Terracotta Army that in past two thousand years since Qin Dynasty, Guanzhong people still remain intact, with almost no change; and there is no one Shanbei person in terra cotta army. Shanbei people, with angular face, white towel on forehead, have an appearance of plain and honest ploughman, but they have the blood of nomadic nation. Helian Bobo, King of Daxia, leading his cavalry "Tiefo", conquered Chang'an; Xi'xia's "Iron Kite" cavalry also wanted to conquer the south; even farmer-born Lizicheng, wearing a hat, a green cloth with narrow sleeve and riding a black horse, established Dashun Regime in Xi'an city. In modern times, Liu Zhidan, "who led troops onto Hengshan" were also determined to fight for communist revolution.

\section{CONCLUSION}

Zhongshan Mountain is not compatible with the Shanbei (Northern Shaanxi) plateau, thus Zhongnan Culture is quite different with Shanbei Nomadic culture, which shows in below aspects: production, cultural psychology, and people's characteristics. Zhongnan Culture lacks mobility, openness and resistance. Zhongnan culture is only a regional culture, and it cannot accept everything, thus its compatibility couldn't be enlarged; its defects should be also recognized, too; that is the attitude of science.

\section{REFERENCES}

[1] Zhou Tao. Nomadic Great Wall-Chapter of Shanbei [M], Changsha: Hunan Literature and Art Publishing House, December 2015, p330.

[2] Yu Qiuyu. Notes of Residence in Mountains [M], Shanghai: Wenhui Publishing, January 2011 edition.

[3] Luo Dajing's. Helin Yulu. Volume 13

[4] Zhou Tao. Nomadic Great Wall-Chapter of Gansu[M], Changsha: Hunan Literature and Art Publishing House, December 2015, p289.

[5] Ren Jiyu. Zen among Peasants and among literati[J], Traditional Culture and Modernization, 1995(1).

[6] Jiao Xun. Flowers and Farming. 